How to Cite

Jain, P., Agarwal, R., Raikwar, V. L., \& Khare, J. (2019). Introduction to satellite education on quality management. International

Journal of Life Sciences \& Earth Sciences, 2(1), 1-4. https://doi.org/10.31295/ijle.v2n1.67

\title{
Introduction to Satellite Education on Quality Management
}

\author{
Paras Jain \\ Silicobyte KDC Katni Degree College, Katni (M.P), India \\ Corresponding author email: parasjainkatni@gmail.com \\ Rishu Agarwal \\ Silicobyte KDC Katni Degree College, Katni (M.P), India \\ Vijya Laxmi Raikwar \\ Silicobyte KDC Katni Degree College, Katni (M.P), India \\ Jaya Khare \\ Silicobyte KDC Katni Degree College, Katni (M.P), India
}

\begin{abstract}
Education provides access to subject matter experts, interaction with career role models. It provides interaction with students in other schools, increases access to information instructional resources, offers opportunities for staff development/in-service training, and increase school community linkages. The rapid growth of satellite networks has generated interest by many state officials in statewide satellite networks. Rural areas are showing great interest in interactive satellite instruction as a way to resolve teacher shortages and meet rigorous graduation requirements. Televised classes permitting live teacher-student interaction via satellite communication systems, and regular telephone lines provide equity increasing quality of educational opportunity.

Keywords---networks, satellite education.
\end{abstract}

\section{Introduction}

The Universalisation of education has become the top priority, especially for developing countries like India. The extension of quality education to remote and rural regions could be possible through satellite communication. EDUSAT helped to possible this herculean task.

The main objectives of satellite education are providing effective teachers training; supplementing the curriculum based teaching, providing access to quality resource persons (higher \& professional education), strengthening the distance education efforts initiated by various agencies, taking education to every nook \& corner of the country, providing access to new technologies (Bailey, \& Cotlar, 1994; Billaiya et al., 2017; Chávez et al., 2018).

EDUSAT project was conceived by ISRO in consultation with MHRD. Having identified that a dedicated satellite could be used for improving the educational scenario in the country, ISRO/DECU embarked on a mission to see ways and means of effective and meaningful utilization of the satellite capacity.

EDUSAT can be used for conventional Radio and Television Broadcasting, interactive radio, and television (phone-in, video on demand.), exchange of data, video conferencing, audio conferencing \& Computer conferencing, and web-based education. It could provide access to the internet; enable the creation of large centralized databases of learning and teaching materials. It would enable nighttime loading of teaching materials as well as a variety of audiobased services (Maba, 2017: Malaiya et al., 2017; Mustika et al., 2017; Sansanwal, 2004). 


\section{Methodology}

To find the status of this trend, student data collected from schools, colleges, educational institutes, and coaching centers. A questionnaire containing questions related to satellite education was prepared (Jain et al., 2017). Data was collected from 400 students. Collected data was tabulated in the table separately to find separate trend value. Year wise user \% calculated, User \% marked according to study level and type of user. User is divided into boys and girls category.

\section{Result and Analysis}

Table 1

Year wise satellite education beneficiaries \%

\begin{tabular}{llll}
\hline Student level & $2013-14$ & $2012-13$ & $2011-12$ \\
\hline School level & 12 & 10 & 7 \\
Higher Education & 23 & 18 & 14 \\
\hline
\end{tabular}

Source: Data collected from institutes

Table 2

Satellite Education beneficiaries

\begin{tabular}{lll}
\hline \multirow{2}{*}{ Student Type } & \multicolumn{2}{c}{ Beneficiary Students } \\
\cline { 2 - 3 } & Boys in \% & Girls in \% \\
\hline School Students & 11 & 14 \\
Higher Education Students & 22 & 24 \\
Technical Education Students & 34 & 37 \\
Medical Education Students & 28 & 31 \\
Management College Students & 28 & 33 \\
Designing Education students & 21 & 25 \\
\hline
\end{tabular}

Source: Data collected from students through a questionnaire

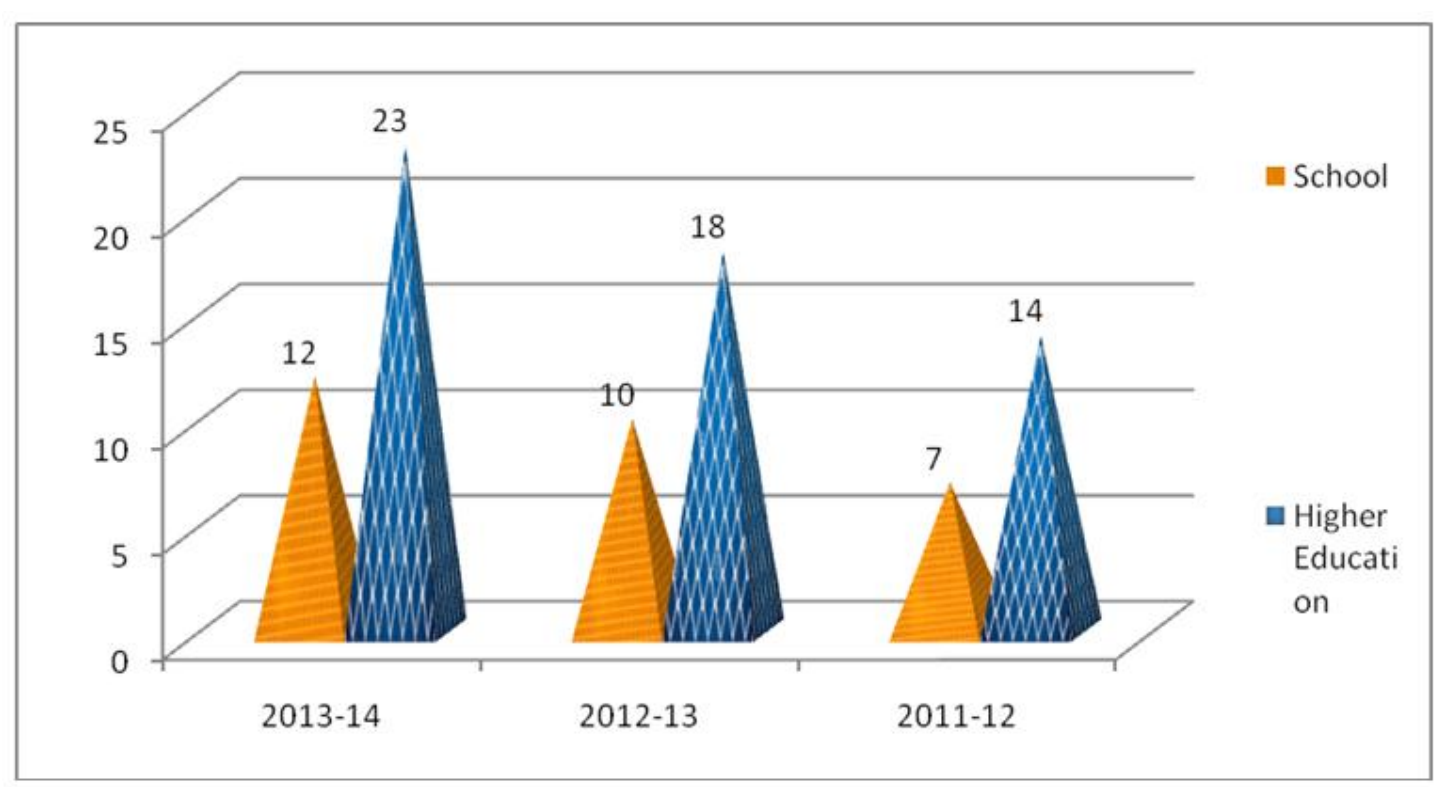

Chart 1. Year wise satellite education beneficiaries $\%$ 


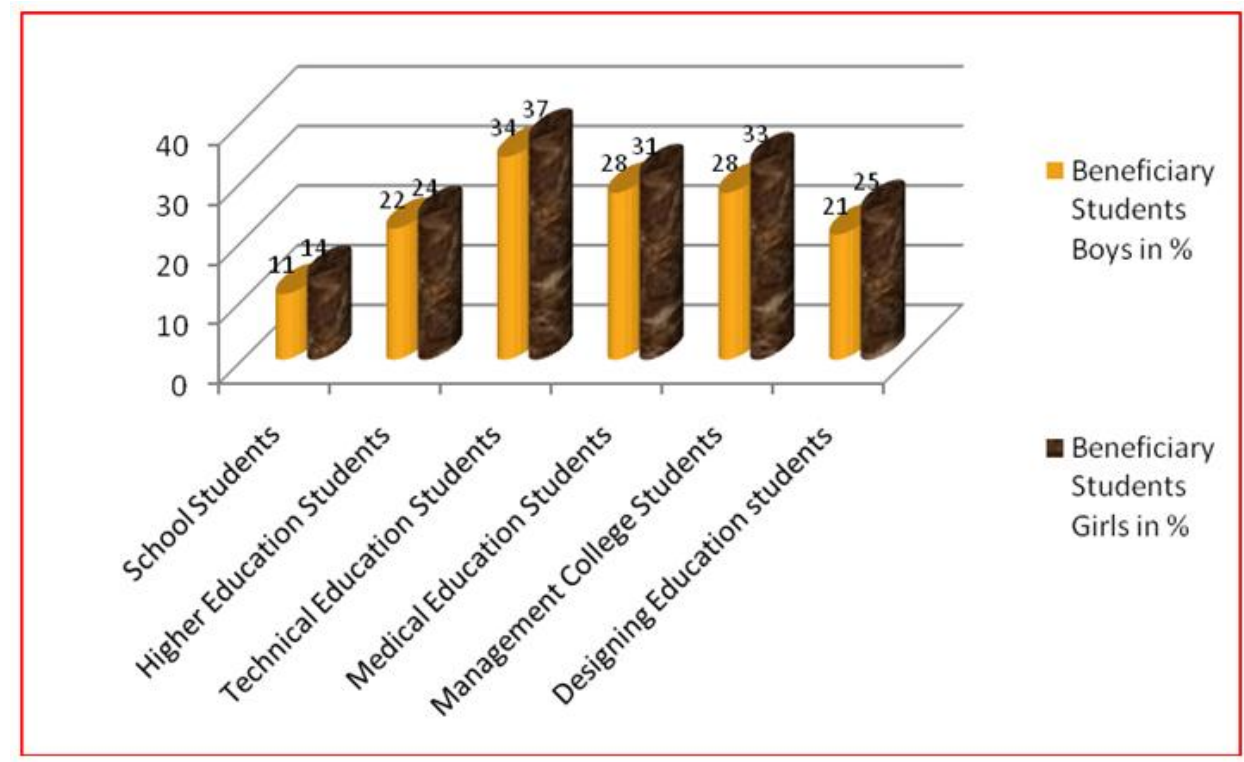

Chart 2. The trend of satellite education

Year wise comparison i.e., Data table-1 shows that school students are taking advantage of satellite education as found $7 \%$ in 2011-12. Higher Education students are also updating their knowledge through satellite education and in this year $14 \%$ were beneficiaries. 10\% school student and 18\% Higher education student beneficiaries are marked in the 2012-13. For the year 2013-14, 12\% of school students, and $23 \%$ higher education students are connected through satellite education.

Data table exhibits that school students are taking advantage of satellite education as found $11 \%$ of boys and $14 \%$ girls. Higher Education students are also increasing learning through satellite education. Govt. established specific technical arrangements in govt. colleges and $22 \%$ boys, $24 \%$ of girls are getting benefits. For technical education students, $\%$ of the benefit is $34 \%$ boys and $37 \%$ of girls are studying. Satellite education is helping for medical students also, $28 \%$ of boys and $31 \%$ of girls are beneficiaries. Management, designing education students are also getting the benefit of satellite education. $28 \%$ of boys, $33 \%$ of girls are taking advantage of management education, $21 \%$ boys and $25 \%$ of girls related to designing education are connected to satellite education.

\section{Conclusion}

Data shows that satellite education made easy administration of education. Our education system has a number of students unable to regular class study and they are getting the help of this system. Easiness of satellite education has strengthened this trend from positively and proved important in the way of quality management. 


\section{References}

Bailey, E. K., \& Cotlar, M. (1994). Teaching via the Internet. Communication Education, 43(2), $184-193$. https://doi.org/10.1080/03634529409378975

Billaiya, R., Malaiya, S., \& Parihar, K. S. (2017). Impact of socio economic trends on students in quality education system. International Journal of Social Sciences and Humanities, 1(1), 16-20. https://doi.org/10.29332/ijssh.v1n1.10

Chávez, S. A. R., \& Quijije, K. K. B. (2018). A Challenge for Teachers of Inclusive Higher Education. International Research Journal of Management, IT and Social Sciences, 5(2), 129-135.

Jain, P. (2017). Effect of online education trend on quality management. International Journal of Health Sciences, 1(1), 1-5. https://doi.org/10.21744/ijhs.v1i1.16

Jain, P., Agarwal, R., Billaiya, R., \& Devi, J. (2017). Women education in rural India. International Journal of Social Sciences and Humanities, 1(1), 21-26. https://doi.org/10.29332/ijssh.v1n1.12

Maba, W. (2017). The implementation of education national standard in the instrument of school accreditation of Bali province education authority. International Research Journal of Engineering, IT \& Scientific Research, 3(4), $1-7$.

Malaiya, S., Shrivastava, A., Prasad, G., \& Jain, P. (2017). Impact of medical education trend in community development. International Journal of Health Sciences, 1(1), 23-27. https://doi.org/10.21744/ijhs.v1i1.19

Mustika, I. W., \& Harini, G. A. (2017). increasing education of family support for decreasing depression level towards elderly. International Journal of Health Sciences, 1(3), 10-16. https://doi.org/10.21744/ijhs.v1i3.46

Sansanwal, D. N. (2004). Information Technology and Teacher. Education, Anweshika. Indian Journal of Teacher Education, 1(2). 